\title{
THE FIRST RECORD OF EUROLEON POLYSPILUS FROM THE SIKHOTE-ALIN STATE NATURE RESERVE, RUSSIA, WITH REMARKS ON ITS BIOLOGY
}

\author{
Maksim E. SergeeviD, Vladimir N. Makarkin* ${ }^{*}$ \\ Federal Scientific Center of the East Asia Terrestrial Biodiversity FEB RAS, Russia \\ "e-mail:vnmakarkin@mail.ru
}

Received: 27.10.2020. Revised: 07.12.2020. Accepted: 21.12.2020.

\begin{abstract}
Larvae of Euroleon polyspilus (Neuroptera, Myrmeleontidae) were found in coniferous-broadleaved forests at two localities in the Middle Sikhote-Alin Mountains (northern Primorsky Krai), including the Sikhote-Alin State Nature Reserve. These findings show that this species can live in a closed canopy forest with dense undergrowth. Their larvae build pitfall traps in any suitable substrate, including dry wood detritus accumulated at the bases of the Pinus koraiensis trunks and produced by beetles (adults or larvae).
\end{abstract}

Key words: ant-lions, Myrmeleontidae, Neuroptera, Protected Area, Russian Far East

Although most ant-lions (Neuroptera, Myrmeleontidae) inhabit treeless arid regions, many genera and species live in forests. Euroleon polyspilus (Gerstaecker, 1885) is one of them. It is distributed in East Asia, including Mongolia, northeastern China, Korea, and eastern Russia (Altaisky Krai, Republic of Altai, Krasnoyarsky Krai, Irkutsk Region, Republic of Buryatia, Republic of Yakutia, Zabaikalsky Krai, Amur Region, Khabarovsky Krai, Primorsky Krai, and Sakhalin Region (Krivokhatsky, 2011)). Krivokhatsky (2011) believed that the $E$. polyspilus occurrence in Ust'-Vilui (Yakutia) is the northern-most record of the Myrmeleontidae family in East Siberia. This species is known from several localities of the Sikhote-Alin Mountains, mainly in its southern part. However, it has not yet been reported from northern Primorsky Krai, in particular Sikhote-Alin State Nature Reserve (see Dobosz et al., 2019).

The larval pitfall traps of the genus Euroleon are usually located in groups in small sandy or dusty sites in landscapes with pronounced relief, like under talus terraces, on slopes and in ditches, grottoes, and at the entrances of caves (Krivokhatsky, 1994). It is known that the $E$. polyspilus larvae build their pitfall traps on slopes, in ditches and quarries (Krivokhatsky, 2011). However, its habitats are little known in the Sikhote-Alin Mountains.

The present research note is based on observations of E. polyspilus larvae from two localities in northern Primorsky Krai: 1) SikhoteAlin State Nature Reserve, the natural boundary of Spornyi in the upper reaches of the River Serebryanka, $470-480 \mathrm{~m}$ a.s.1. $\left(45.1940^{\circ} \mathrm{N}\right.$, $135.9901^{\circ}$ E), 01.08.2020, M. Sergeev; 2) the middle reaches of the River Bolshaya Ussurka, $2 \mathrm{~km}$ north of the village of Dersu, south-eastern slopes, $300-350 \mathrm{~m}$ a.s.1. $\left(45.787408^{\circ} \mathrm{N} 135.311522^{\circ} \mathrm{E}\right)$, 24.08.1991, V. Makarkin. Larvae in both localities were collected in dense, closed canopy forests, far from large openings, rivers or other open places.

The species is found in the coniferousbroadleaved forest in the Sikhote-Alin State Nature Reserve, considered the least disturbed by wildfire or logging. The index tree species is Pinus koraiensis Siebold \& Zucc., but various deciduous trees and shrubs dominate (Fig.). Five or six larval pitfall traps were found in a small (approximately $30 \times 30 \mathrm{~cm}$ ) area of fine-grained sandy soil in the depression from soil pulled up by the roots of a fallen P. koraiensis trunk near the old, narrow logging road with dense undergrowth in places. These traps were spaced closely. One mature larva was determined as Euroleon polyspilus according to the larval descriptions of Krivokhatsky (1994, 2011).

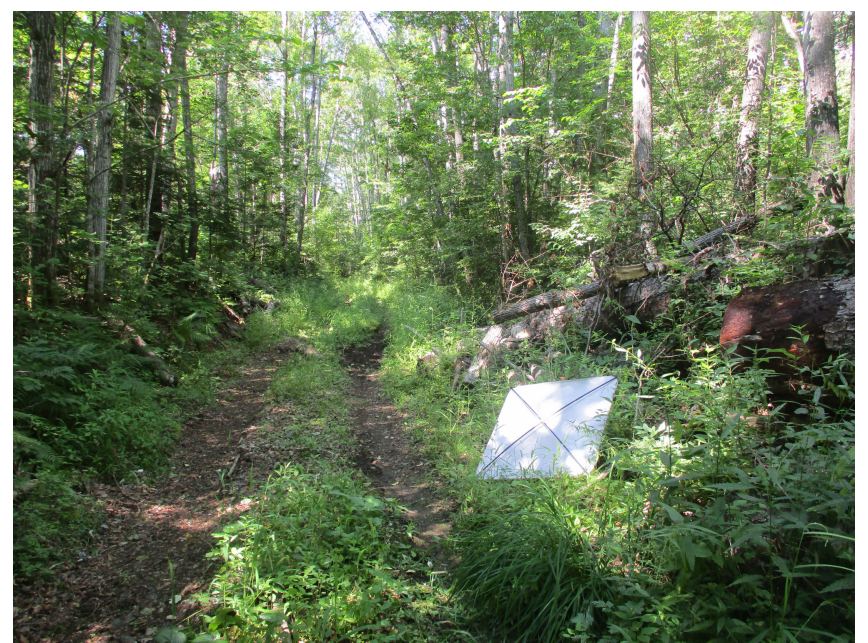

Fig. Locality of Euroleon polyspilus in the Sikhote-Alin State Nature Reserve. The old fallen trunk of Pinus koraiensis on the roadside is the one mentioned in the text (Photo: M.E. Sergeev). 
The forest at the locality of the species near the River Bolshaya Ussurka is similar to where it was collected in the Sikhote-Alin State Nature Reserve. The index tree there was also Pinus koraiensis. However, the forest is characterised by selective logging several decades ago. Deciduous trees and shrubs are diverse. The forest has a closed canopy and dense undergrowth. Forty-six larval pitfall traps of different sizes were found in reddish-brown fine dry wood detritus produced by beetles (adults or larvae) under a large, slightly inclined Pinus koraiensis trunk of more than $1 \mathrm{~m}$ in diameter at the base, between two protruding thick roots. The inclined trunk more or less sheltered the pitfall traps and their larvae from rain. These traps were spaced very closely, as the area of fine wood detritus was small. A dead prey insect (a large Muscidae species) was found in one trap, while others were empty. In addition, a forewing of $E$. polyspilus was found in the spider web near the base of the Pinus koraiensis trunk. Three mature larvae were taken into the laboratory for imago hatching. These larvae moved slowly, not making pitfall traps all autumn and winter, only beginning to do so in early March. One E. polyspilus larva pupated on 28 April 1992, two or three days after it completely consumed a large individual of Blattella germanica (Linnaeus, 1767). The emerged imago was determined to be Euroleon polyspilus.

These new data confirm previous information about the species reported by Krivokhatsky (1994, 2011) and add new details. Euroleon polyspilus is one of the few Russian Far East ant-lions which occur in dense forests. Its larvae use all available small areas of sandy soil and other suitable substrates like fine dry wood detritus, even in dense humid forests. Additionally, Dendroleon jezoensis Okamoto, 1910 is known to live in closed canopy forests in the Russian Far East, but only in southern Primorsky Krai. Another similar species, D. similis Esben-Petersen, 1923, is known in the Russian Far East on the basis of a single adult collected in the extreme south of Primorsky Krai (Krivokhatsky, 2011). The larvae of Dendroleon Brauer, 1866 do not build pitfall traps. Other Russian Far East ant-lions inhabit treeless areas, sparse forests, or exposed river banks in forested areas.

\section{Acknowledgments}

We are grateful to G.A. Nacharkin and E.A. Govorova (Moscow, Russia) for their assistance in field research in the Sikhote-Alin State Nature Reserve. We also thank S. Bruce Archibald (Simon Fraser University, Canada) for editing the English.

\section{References}

Dobosz R., Makarkin V.N., Sergeev M.E. 2019. Contributions to the knowledge of the entomofauna of the Sikhote-Alin Biosphere Reserve. I. Neuropteroid insects: alderflies (Megaloptera: Sialidae), snake-flies (Raphidioptera) and lacewings (Neuroptera). Annals of the Upper Silesian Museum in Bytom Entomology 28(004): 1-30. DOI: 10.5281 /zenodo.3349608

Krivokhatsky V.A. 1994. Ant-lion larvae of the genus Euroleon E.-P. (Neuroptera, Myrmeleontidae). Proceedings of the Kharkov Entomological Society 2: 49-61. [In Russian]

Krivokhatsky V.A. 2011. Ant-lions (Neuroptera: Myrmeleontidae) of Russia. Saint-Petersburg, Moscow: KMK Scientific Press Ltd. 334 p. [In Russian]

\title{
ПЕРВАЯ НАХОДКА ЕUROLEON POLYSPILUS В СИХОТЭ-АЛИНСКОМ ЗАПОВЕДНИКЕ (РОССИЯ) С ЗАМЕЧАНИЯМИ О ЕГО БИОЛОГИИ
}

\author{
М. Е. Сергеев $\mathbb{D}$, В. Н. Макаркин
} Федеральный научный центр биоразнообразия наземной биоты Восточной Азии ДВО РАН, Россия
*e-mail: vnmakarkin@mail.ru

Личинки Euroleon polyspilus (Neuroptera, Myrmeleontidae) найдены в кедрово-широколиственных лесах в двух местонахождениях Среднего Сихотэ-Алиня (северное Приморье), том числе в Сихотэ-Алинском государственном заповеднике. Эти находки показывают, что этот вид может обитать в лесах с сомкнутой кроной и густым подлеском. Личинки строят ловчие воронки в любых подходящих сыпучих субстратах, в том числе в пылевидной сухой древесной трухе, вырабатываемой какими-то жуками-древоточцами (взрослыми или личинками) и скапливающейся у основания стволов корейских кедров (Pinus koraiensis).

Ключевые слова: Myrmeleontidae, Neuroptera, Дальний Восток России, муравьиные львы, особо охраняемая природная территория 